\title{
Autoimmune septin-5 cerebellar ataxia
}

Josephe A. Honorat, MD, PhD, A. Sebastian Lopez-Chiriboga, MD, Thomas J. Kryzer, AS, James P. Fryer, MS, Michelle Devine, MD, Angela Flores, MD, Vanda A. Lennon, MD, PhD, Sean J. Pittock, MD,

and Andrew McKeon, MD

Neurol Neuroimmunol Neuroinflamm 2018;5:e474. doi:10.1212/NXI.0000000000000474
Correspondence

Dr. McKeon

mckeon.andrew@mayo.edu

\section{Abstract}

\section{Objective}

To report a form of autoimmune cerebellar ataxia in which antibodies target septin-5, a guanosine triphosphate (GTP)-binding neural protein involved in neurotransmitter exocytosis.

\section{Methods}

Archived sera and CSF specimens with unclassified synaptic antibodies were re-evaluated by tissue-based indirect immunofluorescence assay. Autoantigens were identified by Western blot and mass spectrometry. Recombinant protein assays (Western blot, cell based, and protein screening array) confirmed antigen specificity.

\section{Results}

Serum and CSF from 6 patients produced identical synaptic immunoglobulin G (IgG) staining patterns of synaptic regions (neuropil) of the mouse cerebrum and cerebellum. The molecular layer of the cerebellum and the thalamus demonstrated stronger immunoreactivity than the midbrain, hippocampus, cortex, and basal ganglia. The antigen revealed by mass spectrometry analysis of immunoprecipitated cerebellar proteins and confirmed by recombinant protein assays was septin-5. All 4 patients with records available had subacute onset of cerebellar ataxia with prominent eye movement symptoms (oscillopsia or vertigo). None had cancer detected. Improvements occurred after immunotherapies (2) or spontaneously (1). One patient died.

\section{Conclusion}

Septin-5 IgG represents a biomarker for a potentially fatal but treatable autoimmune ataxia.

\footnotetext{
From the Department of Laboratory Medicine and Pathology (J.A.H., T.J.K., J.P.F., V.A.L., S.J.P., A.M.), the Department of Neurology (A.S.L.-C., V.A.L., S.J.P., A.M.), and the Department of Immunology (V.A.L.), College of Medicine, Mayo Clinic, Rochester, MN; and Department of Neurology (M.D., A.F.), University of Texas, Southwestern, Dallas.

Funding information and disclosures are provided at the end of the article. Full disclosure form information provided by the authors is available with the full text of this article at Neurology.org/NN.

The Article Processing Charge was funded by the authors.

This is an open access article distributed under the terms of the Creative Commons Attribution-NonCommercial-NoDerivatives License 4.0 (CC BY-NC-ND), which permits downloading and sharing the work provided it is properly cited. The work cannot be changed in any way or used commercially without permission from the journal.
} 


\section{Glossary}

CBA = cell-based assay; IFA = immunofluorescence assay; IgG = immunoglobulin G; IRB = institutional review board.

Cerebellar degeneration leads to disability from loss of balance, incoordination, and speech impairment and can also affect cognitive function. Testing for an autoimmune cause is an important diagnostic endeavor in affected patients, particularly those with a subacute onset and rapidly progressive course. ${ }^{1}$ Affected patients may have an immunotherapyresponsive disease, occult cancer, or both. Herein, we describe 4 adults with a form of autoimmune ataxia unified by detection in serum and CSF of septin-5-specific immunoglobulin G ( $\operatorname{IgG})$.

\section{Methods}

\section{Standard protocol approvals, registrations, and patient consents}

The Mayo Clinic Institutional Review Board (IRB) approved human specimen acquisition and retrospective review of patients' histories (IRB\#, 16-009814).

\section{Protein purification and sequencing, antibody purification, characterization of the target antigen, and development of cell-based immunofluorescence assay}

Indirect immunofluorescence assay (IFA), Western blotting, immunoprecipitation, mass spectrometry, protein microarray, and cell-based transfection assays were used to identify and confirm septin-5 as a target antigen (appendix e-1, links.lww. com/NXI/A55). Testing for previously characterized neural IgGs are also described (appendix e-1). Serum controls tested by IFA ( 470 total) were 317 healthy controls, 63 patients with cancer without neurologic disease, and 90 with other neurologic diseases (Creutzfeldt-Jakob disease [30], CNS systemic lupus erythematous [10], MS [20], and amyotrophic lateral sclerosis [30]). Sera tested by septin-5 IgG cell-based assay (CBA) were 30 healthy and 17 with $\geq 1$ other paraneoplastic antibodies (anti-Hu, 13; collapsin response mediator protein [CRMP]-5-IgG, 7).

\section{Data availability}

All data pertaining to this article are contained within or published as online supplement.

\section{Results}

\section{Characterization of the antigen}

\section{Immunohistochemical distribution of the neural antigen}

Indirect IFA of patients' sera and CSFs using cryosections of murine brain tissue demonstrated a novel identical staining pattern in 6 patients (figure 1, A-F). Specimens strongly stained synaptic regions (neuropil) of the mouse cerebrum and cerebellum. The molecular layer of the cerebellum and the thalamus demonstrated stronger immunoreactivity than the midbrain, hippocampus, cortex, and basal ganglia. The myenteric plexus of the gastric mucosa and the renal glomeruli were also reactive in all cases. The staining pattern superficially resembled that produced by gamma amino butyric acid B receptor antibody; all were negative by cell-based assay for that antibody.

\section{Identification and confirmation of septin-5 as an antigen}

Immunoblotting of mouse brain lysates with sera revealed a common immunoreactive band with approximate molecular weight of $45 \mathrm{kDa}$ among patients only (figure $1 \mathrm{G}$ ). A patient serum and purified IgG eluted from that patient's $45-\mathrm{kDa}$ band demonstrated the same pattern of IgG staining by IFA (figure $1, \mathrm{H}$ and I). To identify the target antigen, immunoprecipitation of the mouse cerebellar extract was performed using pooled IgGs from patients 2 and 6 . Analysis by in-gel digestion and mass spectrometry of proteins captured by IgGs, immobilized by Affi-Gel, assigned the greater number of polypeptides to septin-5 (43 kDa).

To confirm septin-5 as the antigen of interest, first, a recombinant form of septin-5 protein was used for Western blot analysis and probed with serum. Sera from patients 1 to 6 , but not control sera, demonstrated strong immunoreactivity with septin-5 (figure 2A). Second, IFA demonstrated colocalization between commercial septin-5 IgG and patient IgG on mouse brain tissue (figure 2B). Third, mouse brain immunoreactivity of patients' IgGs was abrogated by the absorption of a patient's serum with septin-5 recombinant protein (figure $2 \mathrm{C}$ ), but not with another synaptic protein, adaptor protein 3B2. Fourth, patients' sera and CSFs were tested by indirect IFA on septin-5-transfected HEK 293 cells (CBA, figure e-1, links.lww.com/NXI/A56). Sera and CSFs of all 6 patients were reactive with septin-5 (isoform 1 only). All controls tested by IFA and CBA were negative. Finally, the screening protein microarray was used in a blinded fashion to analyze the antibody profiles in sera available from 5 of the 6 patients (patients 1-5) and 5 controls (healthy and known to be neural antibody negative in our laboratory). Septin-5 was identified as the top candidate autoantigen among all patient sera and was not a candidate antigen among any of the controls. In each patient serum, septin-5 had the highest fold change in signal intensity relative to the controls and the lowest $p$ value (table e-1, links.lww.com/NXI/A57). Because septin- 4 and septin-7 were also identified as lower probability candidates, Western blots using recombinant forms of those proteins were undertaken using all 6 patient sera. Patient 3 had coexisting septin-4 IgG detected, and the remaining 

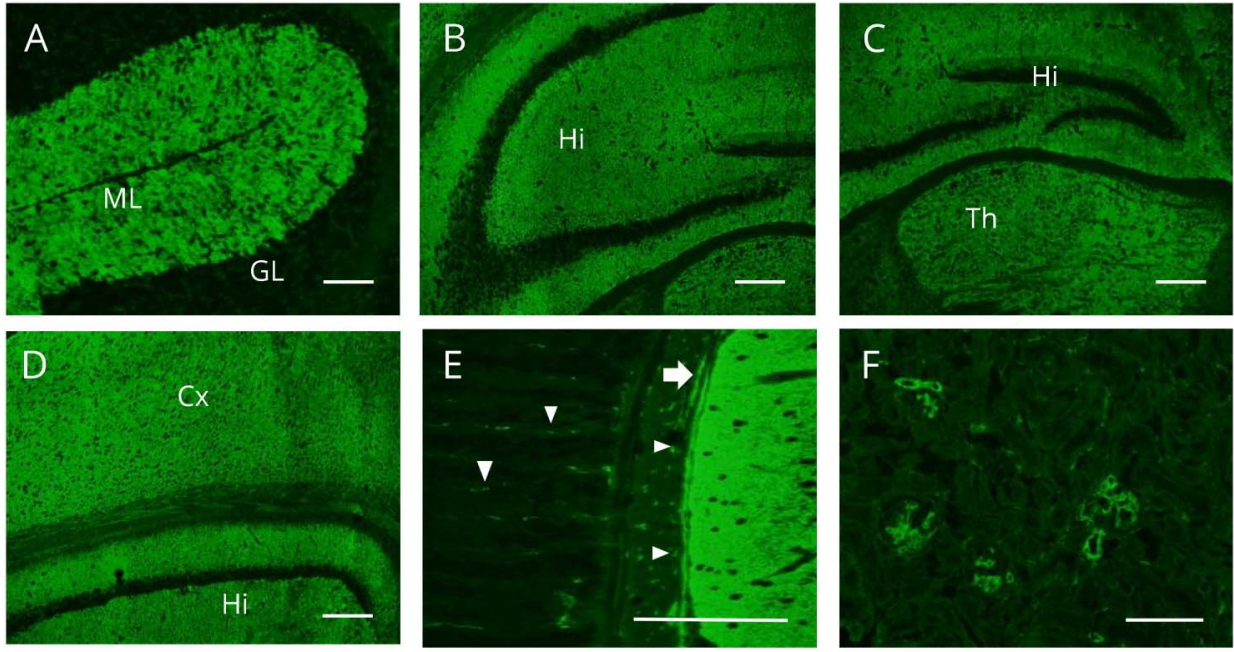

G

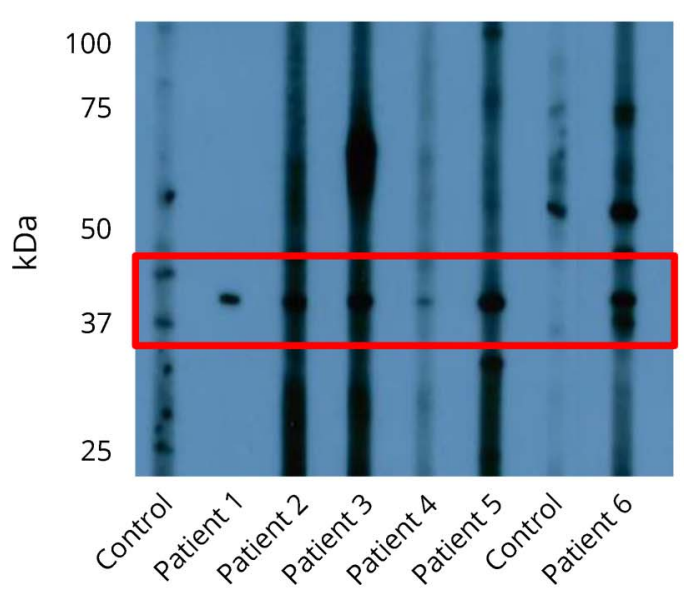

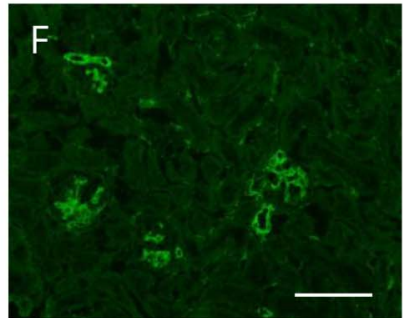
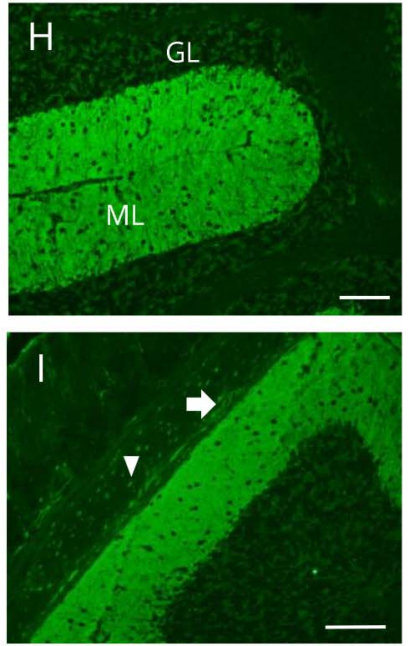

(A-F) Patient serum produces synaptic staining patterns of cerebellar ML more than GL (A); Hi (B, C, and D); Th (C); Cx (D); enteric ganglia (arrow) and nerves (arrow heads) (E); and renal glomeruli (F). (G) Mouse cerebrum proteins, reduced, denatured, and separated electrophoretically, produced a $\sim 45-\mathrm{kDa}$ band when probed with patients' IgGs (patients 1-6) but not healthy controls' IgGs. ( $\mathrm{H}$ and I) Application of IgG eluted from a nitrocellulose strip containing the $\sim 45-\mathrm{KDa}$ band to mouse tissue reproduced the patient's IgG staining pattern (E). Scale bar $=5 \mathrm{~mm}$. Cx = cerebral cortex; $\mathrm{GL}=$ granular layer; $\mathrm{Hi}=$ hippocampus; $\mathrm{ML}=$ molecular layer; $\mathrm{Th}$ $=$ thalamus. patients were septin-4 IgG and septin-7 IgG negative. Other coexisting neural IgGs included low positive values of IgGs reactive with $\mathrm{N}$-type calcium channel or glutamic acid decarboxylase, $65-\mathrm{kDa}$ isoform (2 each).

\section{Clinical features}

Four of the 6 patients were women. The median age of symptom onset was 59 years (range, $47-62$ years). The median septin-5 IgG antibody value in serum for the 6 patients was 1 : 15,360 (range, 1:7,680-1:15,360; normal value $\leq 120$ ).

Clinical information was available for 4 patients $(2$ men and 2 women; table 1), 1 seen at Mayo Clinic. The median followup duration was 35 months (range, 1-77). All 4 patients had a rapidly progressive cerebellar syndrome. One patient had severe vertigo, nausea, and vomiting at onset, before developing cerebellar ataxia. Two other patients had prominent oscillopsia at onset. Two patients had accompanying tremulousness. One patient became encephalopathic and obtunded in addition, later in the clinical course. The 1 patient with routine CSF parameters available had an increased IgG synthesis rate. Head MRI (available in 2 patients) demonstrated cerebellar atrophy in 1 early in the disease course (figure 2D) and was unremarkable in 1. None had cancer identified. One patient spontaneously recovered. Immunotherapies used in 2 other patients with treatment and outcome data available included corticosteroids (2), plasma exchange (1), and IV immune globulin (1). Improvements were robust and sustained in 1 patient and transient in another patient who died 6 months later.

\section{Discussion}

Septin-5 IgG is a biomarker of a rapidly progressive, but treatable, form of autoimmune cerebellar ataxia. To date, based on limited clinical experience, we have not encountered a paraneoplastic case, although septin-5 expression is known to occur in neuroendocrine pancreatic tumors. ${ }^{2}$ Our data support autoimmune septin-5 cerebellar ataxia being a severe neurologic disorder, treatable in some but potentially fatal. Septin-5-IgG was detectable in both serum and CSF, although 


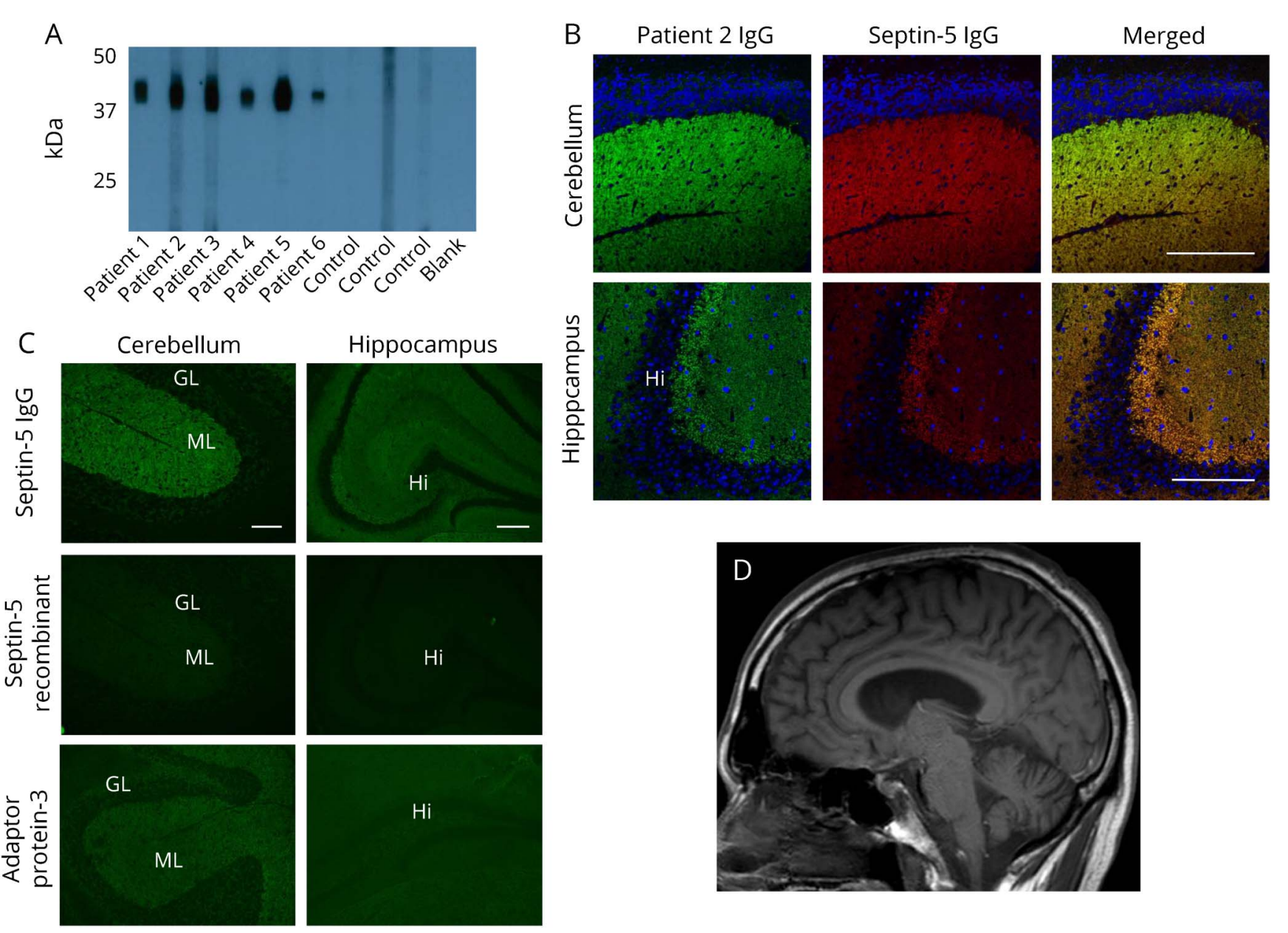

(A) Western blot shows IgGs in all 6 patients' sera binding to septin-5 recombinant protein (lanes 1-6); IgGs in healthy controls' sera are nonreactive (lanes 7-9). (B) Confocal microscopy shows patient IgGs colocalizing with septin-5 immunoreactivity in the mouse cerebellum and hippocampus. (C) Immune absorption of patient IgGs. Septin-5-IgG is robustly absorbed by the septin-5 recombinant protein, but not by the same amount of another synaptic protein, adaptor protein 3. (D) T1 sagittal MRI of the head from patient 5 demonstrating cerebellar atrophy. $\mathrm{GL}=$ granular layer; $\mathrm{Hi}=$ hippocampus; IgG = immunoglobulun $\mathrm{G}$; $\mathrm{ML}=$ molecular layer. Scale bar $=5 \mathrm{~mm}$.

we do not have data to indicate whether the immune response is generated intrathecally, systemically, or both.

Septins are a family of 13 cytoskeletal GTP-binding proteins with diverse functions. ${ }^{3,4}$ In the CNS, they play roles in exocytosis and dendritic branching. ${ }^{10}$ At synapses, septins provide a membrane-associated scaffold for vesicular SNAP (soluble N-ethylmaleimide-sensitive factor attachment protein) receptor (SNARE) proteins such as SNAP25 and its chaperones to interact and have regulatory effects on exocytosis at the plasma membrane that are either stimulatory (e.g., septin-2) or inhibitory (e.g., septin-5). ${ }^{5-7}$ At this early stage, the pathophysiology of septin-5 autoimmunity is unknnown. Similar to amphiphysin, septin-5 has extracellular expression during exocytosis and therefore the potential to interact with a pathogenic septin-5-IgG. ${ }^{8}$

As well as being expressed in CNS presynaptic terminals, septin-5 colocalizes with septin-7 and septin-11 at the branch points of neuronal dendrites. ${ }^{9}$ There are 2 septin- 5 isoforms that differ in amino acid sequences at their $\mathrm{N}$-termini, variant (v)1, the full-length adult protein, with which our patient specimens alone were reactive, and $v 2$, a truncated neonatal form. ${ }^{3}$ Septin-5 deficiency has been associated with a neurobehavioral phenotype in mice and humans. ${ }^{10}$ Septins in general are capable of both self-association and formation of diverse function-defining heteromeric complexes with other septins. Coexisting septin-4 antibody was confirmed in 1 of our patients. A polyclonal response against various septin proteins within a heteromeric complex could occur in these patients.

At this early stage, proteomic arrays seem to be useful screening investigative tools for novel neural antibody discovery, and future iterations may have utility in clinical diagnostic laboratories. Currently, testing for autoimmune septin-5 cerebellar ataxia can be tested for with optimum specificity by incorporating into a standard laboratory 
Table Clinical, testing, treatment, and outcome data of 4 patients with autoimmune septin-5 cerebellar ataxia

\begin{tabular}{|c|c|c|c|c|c|c|c|c|c|c|c|c|}
\hline $\begin{array}{l}\text { Patient } \\
\text { no./sex/ } \\
\text { age/race }\end{array}$ & $\begin{array}{l}\text { Clinical } \\
\text { summary }\end{array}$ & Cancer & $\begin{array}{l}\text { Septin-5 } \\
\text { lgG+ }\end{array}$ & $\begin{array}{l}\text { Coexisting } \\
\text { antibodies } \\
\text { (nmol/L) }\end{array}$ & $\begin{array}{l}\text { Coexisting } \\
\text { autoimmune } \\
\text { disease }\end{array}$ & $\begin{array}{l}\text { Inflammatory } \\
\text { CSF findings }\end{array}$ & $\begin{array}{l}\text { Brain } \\
\text { MRI }\end{array}$ & $\begin{array}{l}\text { Immunotherapy } \\
\text { (improved?) }\end{array}$ & $\begin{array}{l}\text { Neurologic } \\
\text { nadir }\end{array}$ & $\begin{array}{l}\text { Neurologic } \\
\text { zenith }\end{array}$ & $\begin{array}{l}\mathrm{mRS} \\
\text { at the } \\
\text { last F/ } \\
\mathrm{U}\end{array}$ & $\begin{array}{l}\text { Disease } \\
\text { duration } \\
\text { (symptom } \\
\text { onset to the } \\
\text { last follow-up/ } \\
\text { death, mo) }\end{array}$ \\
\hline 2/F/60/C & $\begin{array}{l}\text { Subacute onset } \\
\text { vertigo, intractable } \\
\text { nausea, and vomiting, } \\
\text { initially diagnosed as } \\
\text { labyrinthitis, followed } \\
\text { by gait ataxia }\end{array}$ & No & $\begin{array}{l}\text { Serum \& } \\
\text { CSF }\end{array}$ & None & No & NA & Normal & $\begin{array}{l}\text { None, resolved } \\
\text { spontaneously }\end{array}$ & $\begin{array}{l}\text { Use of } \\
\text { walker }\end{array}$ & $\begin{array}{l}\text { Ambulated } \\
\text { independently }\end{array}$ & 0 & 77 \\
\hline $\begin{array}{l}\text { 3/M/62I } \\
\text { NA }\end{array}$ & $\begin{array}{l}\text { Rapidly progressive } \\
\text { eye movement } \\
\text { disorder, truncal/limb } \\
\text { myoclonus, followed } \\
\text { by encephalopathy }\end{array}$ & NA & $\begin{array}{l}\text { Serum } \\
\text { and CSF }\end{array}$ & $\begin{array}{l}\text { GAD65 } 0.17 \\
\text { and septin- } \\
4\end{array}$ & NA & NA & NA & NA & NA & NA & NA & 1 \\
\hline $\begin{array}{l}4 / F / 59 / \\
A A\end{array}$ & $\begin{array}{l}\text { Rapidly progressive } \\
\text { spinocerebellar } \\
\text { syndrome with tremor }\end{array}$ & $\begin{array}{l}\text { No (investigations } \\
\text { including age- } \\
\text { related cancer } \\
\text { screening and PET) }\end{array}$ & $\begin{array}{l}\text { Serum } \\
\text { and CSF }\end{array}$ & CCN 0.06 & No & NA & NA & $\begin{array}{l}\text { Oral steroids, } \\
\text { PLEX (initially) }\end{array}$ & Bedbound & Death & 6 & 6 \\
\hline $5 / \mathrm{M} / 47 / \mathrm{C}$ & $\begin{array}{l}\text { Headache, followed by } \\
\text { subacute cerebellar } \\
\text { ataxia and prominent } \\
\text { oscillopsia }\end{array}$ & $\begin{array}{l}\text { No (investigations } \\
\text { including age- } \\
\text { related cancer } \\
\text { screening, CT body, } \\
\text { and ultrasound of } \\
\text { the testes) }\end{array}$ & $\begin{array}{l}\text { Serum } \\
\text { (CSF NA) }\end{array}$ & $\begin{array}{l}\text { CCN } 0.14 \\
\text { and GAD65 } \\
28.1\end{array}$ & No & $\begin{array}{l}\text { Protein } 70 \mathrm{mg} / \\
\mathrm{dL} \text {; increased } \\
\text { IgG synthesis } \\
\text { rate }\end{array}$ & $\begin{array}{l}\text { Cerebellar } \\
\text { vermis } \\
\text { atrophy }\end{array}$ & $\begin{array}{l}\text { IVMP, followed by } \\
\text { IVIg maintenance } \\
\text { (yes) }\end{array}$ & Use of cane & $\begin{array}{l}\text { Ambulated } \\
\text { independently, } \\
\text { with residual } \\
\text { ataxic signs }\end{array}$ & 1 & 54 \\
\hline
\end{tabular}

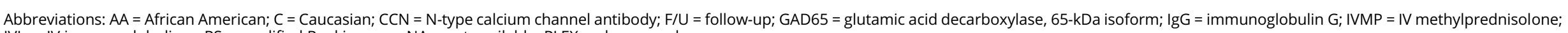
IVIg = IV immunoglobulin; mRS = modified Rankin score; NA = not available; PLEX = plasma exchange. 
algorithm, which uses a screening tissue-based assay, followed by a confirmatory molecular assay.

\section{Author contributions}

J.A. Honorat and A.S. Lopez-Chiriboga: data collection; analysis and interpretation of data; and drafting of the manuscript. T.J. Kryzer and J.P. Fryer: data collection; analysis and interpretation of data; and critical revision of the manuscript. M. Devine, A. Flores, V.A. Lennon, and S.J. Pittock: data collection and analysis and critical revision of the manuscript. A. McKeon: study concept and design; data collection; analysis and interpretation of data; drafting and critical revision of the manuscript; and study supervision.

\section{Acknowledgment}

The authors thank the Mayo Center for Individualized Medicine for research funding and Vickie Mewhorter for excellent technical support.

\section{Study funding}

This study was sponsored by the Center for Individualized Medicine, Mayo Clinic.

\section{Disclosure}

J.A. Honorat has a patent pending for Septin-5-IgG as biomarker of autoimmune neurological disease. A.S. LopezChiriboga reports no disclosures. T.J. Kryzer holds a patent for and receives royalties from Marker for Neuromyelitis Optica, which has been licensed to commercial entities. J.P. Fryer and M. Devine report no disclosures. A. Flores received travel funding and/or speaker honoraria form Biogen and Multiple Sclerosis Association of America and served on the speaker's bureau of Biogen. V.A. Lennon receives royalties from RSR/Kronus for sale of aquaporin-4 autoantibody testing kits and for commercial aquaporin-4 autoantibody testing performed outside Mayo Clinic and received research support from MN Partnership for Biotechnology and Medical
Genomics. S.J. Pittock has a patent pending for Septin-5 and MAP1B autoantibodies as biomarkers of neurological autoimmunity; has consulted for Alexion Pharmaceuticals and MedImmune (with fees being paid to Mayo Clinic); and received research support from Grifos, MedImmune, Alexion, and NIH, S.J. Pittock and Mayo Clinic have a financial interest in patents (\#12/678,350 filed 2010 and \#12/573,942 filed 2008) that relate to functional AQP4/NMO-IgG assays and NMO-IgG as a cancer marker. A. McKeon has a patent pending for Septin 5 and MAP1B as markers of neurological autoimmunity and paraneoplastic disorders; has consulted for Grifos, MedImmune, and Euroimmun (no personal compensation); and received research support from MedImmune and Euroimmun. Full disclosure form informaton provided by the authors is available with the full text of this article at Neurology.org/NN.

Received March 1, 2018. Accepted in final form May 21, 2018.

\section{References}

1. Jarius S, Wildemann B. "Medusa-head ataxia": the expanding spectrum of Purkinje cell antibodies in autoimmune cerebellar ataxia: part 1: anti-mGluR1, anti-Homer-3, antiSj/ITPR1 and anti-CARP VIII. J Neuroinflammation 2015;12:166.

2. Capurso G, Crnogorac-Jurcevic T, Milione M, et al. Peanut-like 1 (septin 5) gene expression in normal and neoplastic human endocrine pancreas. Neuroendocrinology 2005;81:311-321.

3. Asada A, Takahashi J, Taniguchi M, et al. Neuronal expression of two isoforms of mouse Septin 5. J Neurosci Res 2010;88:1309-1316.

4. Neubauer K, Zieger B. The Mammalian septin interactome. Front Cell Dev Biol 2017; $5: 3$.

5. Tokhtaeva E, Capri J, Marcus EA, et al. Septin dynamics are essential for exocytosis. J Biol Chem 2015;290:5280-5297.

6. Amin ND, Zheng YL, Kesavapany S, et al. Cyclin-dependent kinase 5 phosphorylation of human septin SEPT5 (hCDCrel-1) modulates exocytosis. J Neurosci 2008;28: 3631-3643.

7. Yang YM, Fedchyshyn MJ, Grande G, et al. Septins regulate developmental switching from microdomain to nanodomain coupling of $\mathrm{Ca}(2+)$ influx to neurotransmitter release at a central synapse. Neuron 2010;67:100-115.

8. Geis C, Weishaupt A, Hallermann S, et al. Stiff person syndrome-associated autoantibodies to amphiphysin mediate reduced GABAergic inhibition. Brain 2010;133: 3166-3180.

9. Kaplan C, Steinmann M, Zapiorkowska NA, Ewers H. Functional redundancy of septin homologs in dendritic branching. Front Cell Dev Biol 2017;5:11.

10. Bartsch I, Sandrock K, Lanza F, et al. Deletion of human GP1BB and SEPT5 is associated with Bernard-Soulier syndrome, platelet secretion defect, polymicrogyria, and developmental delay. Thromb Haemost 2011;106:475-483. 


\section{Neurology \\ Neuroimmunology \& Neuroinflammation}

Autoimmune septin-5 cerebellar ataxia

Josephe A. Honorat, A. Sebastian Lopez-Chiriboga, Thomas J. Kryzer, et al.

Neurol Neuroimmunol Neuroinflamm 2018;5;

DOI 10.1212/NXI.0000000000000474

This information is current as of July 9, 2018

Neurol Neuroimmunol Neuroinflamm is an official journal of the American Academy of Neurology.

Published since April 2014, it is an open-access, online-only, continuous publication journal. Copyright

Copyright $\odot 2018$ The Author(s). Published by Wolters Kluwer Health, Inc. on behalf of the American

Academy of Neurology.. All rights reserved. Online ISSN: 2332-7812.

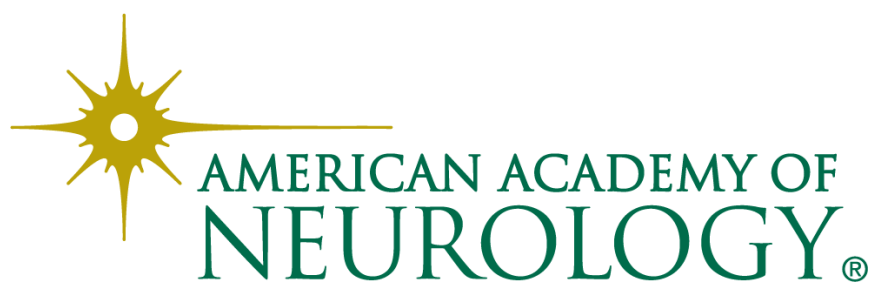




\section{Updated Information \& Services}

References

Citations

Subspecialty Collections

\section{Errata}

\section{Permissions \& Licensing}

\section{Reprints}

including high resolution figures, can be found at: http://nn.neurology.org/content/5/5/e474.full.html

This article cites 10 articles, 2 of which you can access for free at: http://nn.neurology.org/content/5/5/e474.full.html\#\#ref-list-1

This article has been cited by 1 HighWire-hosted articles: http://nn.neurology.org/content/5/5/e474.full.html\#\#otherarticles

This article, along with others on similar topics, appears in the following collection(s):

All Clinical Neurology

http://nn.neurology.org//cgi/collection/all_clinical_neurology Autoimmune diseases

http://nn.neurology.org//cgi/collection/autoimmune_diseases

Gait disorders/ataxia

http://nn.neurology.org//cgi/collection/gait_disorders_ataxia

Paraneoplastic syndrome

http://nn.neurology.org//cgi/collection/paraneoplastic_syndrome

An erratum has been published regarding this article. Please see next page or:

/content/6/1/e534.full.pdf

Information about reproducing this article in parts (figures,tables) or in its entirety can be found online at:

http://nn.neurology.org/misc/about.xhtml\#permissions

Information about ordering reprints can be found online: http://nn.neurology.org/misc/addir.xhtml\#reprintsus

Neurol Neuroimmunol Neuroinflamm is an official journal of the American Academy of Neurology.

Published since April 2014, it is an open-access, online-only, continuous publication journal. Copyright

Copyright $\odot 2018$ The Author(s). Published by Wolters Kluwer Health, Inc. on behalf of the American Academy of Neurology.. All rights reserved. Online ISSN: 2332-7812.

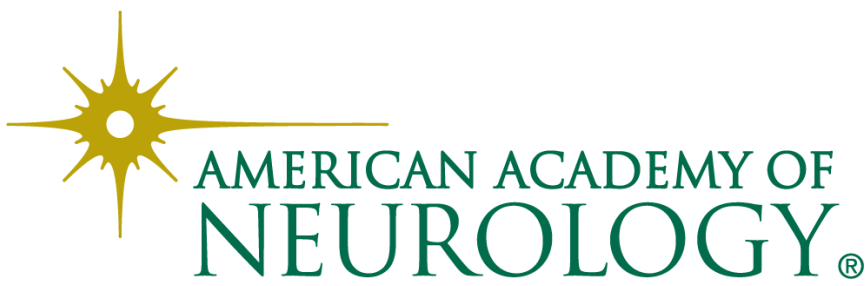




\section{Autoimmune Septin-5 Cerebellar Ataxia}

Neurol Neuroimmunol Neuroinflamm 2019;6:e534. doi:10.1212/NXI.0000000000000534

In the article, “Autoimmune Septin-5 Cerebellar Ataxia” by Honorat, et al. ${ }^{1}$, first published online on July 9, 2018, the scale bar measurement for Figure 1 should read as Scale bar, A, H and I, $100 \mu \mathrm{m}$; B, C, and D, $200 \mu \mathrm{m}$; E and F, $150 \mu \mathrm{m}$; the scale bar measurement for Figure 2 should read as Scale bar, B, $200 \mu \mathrm{m}$ (top), $150 \mu \mathrm{m}$ (bottom); C, $100 \mu \mathrm{m}$ (left), $200 \mu \mathrm{m}$ (right); and the scale bar measurement for the e-figure legend should read as $75 \mu \mathrm{m}$. The authors regret the error.

\section{Reference}

1. Honorat JA, Lopez-Chiriboga AS, Kryzer TJ, et al. Autoimmune Septin-5 Cerebellar Ataxia. Neurol Neuroimmunol Neuroinflamm 2018;5:e474. 